Article

\title{
Partner Strategic Capabilities for Capturing Value from Sustainability-Focused Multi-Stakeholder Partnerships
}

\author{
Adriane MacDonald ${ }^{1, *(\mathbb{D}}$, Amelia Clarke ${ }^{2}{ }^{(D}$, Lei Huang ${ }^{3}$ and M. May Seitanidi ${ }^{4}$ \\ 1 Dhillon School of Business, University of Lethbridge, 4401 University Drive W, Lethbridge, \\ AB T1K 3M4, Canada \\ 2 School of Environment, Enterprise and Development (SEED), University of Waterloo, 200 University \\ Avenue W, Waterloo, ON N2L 3G1, Canada; amelia.clarke@uwaterloo.ca \\ 3 School of Business, State University of New York at Fredonia, 280 Central Avenue, Fredonia, NY 14063, USA; \\ lei.huang@fredonia.edu \\ 4 Kent Business School, University of Kent, Canterbury, Kent CT2 7NZ, UK; m.m.seitanidi@kent.ac.uk \\ * Correspondence: adriane.macdonald@uleth.ca; Tel.: +(403)-317-2885
}

Received: 12 December 2018; Accepted: 17 January 2019; Published: 22 January 2019

\begin{abstract}
As social and ecological problems escalate, the role of collective capacity and knowledge is becoming more critical in reaching solutions. This capacity and knowledge are dispersed among diverse stakeholder organizations. Thus, organizations in the private, public and civil society sectors are experiencing pressure to address these complex challenges through collaborative action in the form of multi-stakeholder partnerships. One major challenge to securing and maintaining partner engagement in these voluntary collaborative initiatives is defining the value proposition for prospective and existing partner organizations. Understanding the relationship between different forms of partner involvement and the subsequent resources that partners stand to gain is necessary to articulate the value proposition of the partnership to partners. This study conducts a survey of partner organizations from 15 different sustainability-focused multi-stakeholder partnerships in Canada. We compare three partner strategies for implementation and value capture and discover that each strategy is associated with different partner-level resource outcomes. Our findings indicate that product stewardship strategies are associated with financial and organizational capital, marketing and promotion with human capital, and internal implementation structures with shared capital. This study has implications for multi-stakeholder partnership researchers and practitioners because it suggests the possibility that certain partner-level outcomes could rely on the partner, as well as partnership implementation strategies.
\end{abstract}

Keywords: community sustainability plans; cross-sector social partnership; Local Agenda 21; multi-stakeholder partnerships; partner outcomes; resource-based view theory; strategic capabilities; sustainable development

\section{Introduction}

Organizations in private, public and civil society sectors are increasingly confronted with complex sustainable development challenges, such as resource scarcity or other risks associated with climate change and unsustainable consumption. One collaborative approach to deal with these issues is through multi-stakeholder partnerships, which bring together the knowledge and resources of many stakeholders to address a shared agenda [1,2]. Exemplifying this is the United Nations (UN) Sustainable Development Goal (SDG) \#17, which recommends that partnerships be used to accomplish global SDG targets because single organizations infrequently possess the skills 
and resources to address complex issues related to sustainability [3]. However, a significant barrier to the success of sustainability-focused multi-stakeholder partnerships is the ongoing maintenance of partner engagement and commitment [4,5]. For example, these partnerships often enjoy high energy and involvement from their partner organizations during the formulation stage, but it is typical for this enthusiasm to wane over time, which can threaten the viability of the partnership and thus its ability to achieve its goals [6]. This paper seeks to address this challenge by improving what is understood about how partner implementation and value capture strategies influence their outcomes.

Cross-sector partnerships—of which multi-stakeholder partnerships are a subset-have various forms and purposes [7]. For example, these partnerships can be bi-sector, involve as few as two partners, and address relatively straightforward issues, for instance the well-known private-public partnership (PPP) model often involves a public sector partner joining with a private sector partner to implement an infrastructure project or administer a public service. In contrast, these partnerships can also be trisector, involve several hundred or even thousand partners and address complex social challenges. One such example is the Landcare partnership in Australia, which mobilises several partners from each of the public, private and civil society sectors to achieve sustainable farming through implementing responsible land management practices [2]. This heterogeneity in partnership form and purpose make it challenging to establish a succinct and accurate definition for all partnerships captured under the cross-sector umbrella [8]. Even among the subgroup of cross-sector social partnership researchers that focus on multi-stakeholder partnerships there are definitional debates. At the core of these debates are partnership attributes such as voluntary versus obligatory partner involvement [8], trisector versus bisector partner composition [9], and formal versus informal governance structures [10]. The partnership's purpose is also a central point of discussion, on one hand, some researchers and practitioners propose that the term multi-stakeholder partnership refers only to those partnerships that advance the UN's sustainable development agenda [9]. On the other hand, the term is also used by researchers in fields such as health sciences [11] and sports management [12] to describe partnerships that do not necessarily conform with the UN's definitional parameters. Such partnership attributes and functions are likely to impact partner expectations and outcomes, as well as other variables, and as such provide context for situating and interpreting research findings.

This paper examines large tri-sector multi-stakeholder partnerships that address local sustainable development issues by formulating and implementing a community sustainability or Local Agenda 21 (LA21) plan [13]. LA21 is rooted in United Nations programs and involves a local government initiated collaborative process that results in a community sustainability plan [14]. For reference, a community sustainability plan includes the shared long-term sustainability vision of a local community, and the goals and actions needed to overcome social, environmental, and economic challenges. LA21 partnerships are also voluntary, self-organizing, and tend to have a large and heterogeneous partner base [9]. For example, the partnerships examined in this paper include partner organizations such as environmental NGOs, chamber of commerce, neighbourhood associations, hospitals, universities, local government departments, and businesses.

Recently, the advantages of multi-stakeholder partnerships have received a fair amount of research attention. Yet, comparatively few of these studies extend beyond identifying outcomes to understanding the underlying processes that facilitate these outcomes [15]. Management researchers that study outcome generating processes tend to focus on partner characteristics, such as goal congruence between partner organizations $[5,16,17]$. Some research has examined the impacts of partnership implementation strategies on outcomes, but these studies typically focus on the partnership-level, exploring governance structure, coordinating processes, or the patterns of partner interactions $[10,18]$. These studies do not, however, examine how partner-level implementation strategies impact outcomes, such as partner access to resources or competitive advantage. This is a significant research gap because many large trisector multi-stakeholder partnerships are problem focused, and unlike small bisector cross-sector partnerships, are not necessarily adapted to meet both individual partner organization and shared partnership goals to the same degree $[19,20]$. 
The prioritization of the partnership's goals in multi-stakeholder partnerships mean that the benefits to partners are often a by-product rather than a focal point of implementation, and as a result, these partnerships can struggle to maintain partner engagement $[13,21]$. The research presented in this paper contributes to the multi-stakeholder partnership literature by improving what is understood about how partners capture value from their partnership activities. In doing so, this research aims to show how multi-stakeholder partnerships, like LA21 partnerships, can maintain ongoing partner engagement even when partner participation is voluntary and needed over a long time period. It also contributes by showing that different partner strategies result in different types of resources gained. These findings have implications for partners because they suggest that when partners understand their organization's goals for being a partner and develop their strategic capabilities accordingly, they have the potential to turn partnership-level resources into a competitive advantage for their organization.

This article takes a resource-based view (RBV) of partner value capture strategies to explore two research questions: (1) How do partner organizations capture value from sustainability-focused multi-stakeholder partnerships? And (2), do different strategies for value capture result in different bundles of resources for partners? To answer these research questions, we investigate the strategic capabilities and resource gains of partners in multi-stakeholder partnerships that implement LA21 inspired community sustainability plans.

In the following section we extend a RBV to the multi-stakeholder partner context by using it to conceptualize the strategic value of partnership-level resources to partners. We then draw on partnership and corporate sustainability literature to propose three strategic capabilities that partners can use to operationalize partnership-level resources. Next, in the Methods section, we discuss our approach to data collection and provide an overview of our survey measures. We then report findings from four regression models and conclude with a discussion about the implications of our study's results for research, multi-stakeholder partnerships, and partners.

\section{Theoretical Background}

\subsection{A Strategic Perspective of Partnership and Partner Outcomes}

Resource-oriented perspectives offer a significant body of research to explain what makes certain resources more valuable than others and how organizations organize to capture value from their resources or bundles of resources [17,22-24]. While language among RBV scholars has varied, there is some agreement on the attributes that contribute to the strategic worth of a resource. For example, a resource is considered valuable when it contributes to an organization's core capabilities [22], rare when it is organization specific [25], and inimitable when it is derived from casually ambiguous or socially complex processes [22]. However, it is not enough for an organization to have resources that are valuable, rare, and inimitable because to extract the value embedded in these resources the organization must also be 'organized to capture value' [26]. In other words, the organization must possess specific strategic capabilities that operationalize its resources [27]. Examples of strategic capabilities include processes, procedures, structures, knowledge, or strategies that help to organize resources in a way that will benefit the organization [28].

In a RBV, there are two overarching types of resources: tangible resources and intangible resources [24]. Tangible resources such as land, facilities and financial assets are valuable but easy for competitors to replicate. Thus, they are not typically the source of sustained competitive advantage for organizations [26,27]. On the other hand, intangible resources-such as those resources that are knowledge- and relationship-based-can contribute to sustained competitive advantage when they possess characteristics that obscure the path of their attainment [22]. Two characteristics that contribute to a resource's opacity are causal ambiguity and social complexity [29]. A resource has characteristics of causal ambiguity when it is unclear to outsiders what inputs contributed to an outcome or how the resource was obtained [30]. For example, tacit resources, comprised of employee skill sets and capabilities, are causally ambiguous because they are established over time through complex 
compilations of individualized experiences, expertise, practice, and professional development [31]. Whereas resources attained through social complexity result from coordinated actions and interactions among groups of individuals [22]. Examples of socially complex resources are organizational culture, trust, reputation, and positive interpersonal relationships [26].

Arguably, multi-stakeholder partnerships create the conditions for partners to access valuable resources with characteristics of causal ambiguity and social complexity [17]. In the case of multi-stakeholder partnerships that implement community sustainability plans in the formulation stage, local organizations join together to establish a sustainability vision for their community, set sustainability goals and develop strategies and targets for achieving their vision $[14,20]$. This process of strategic planning connects a diverse group of local organizations and creates opportunities for those involved to build relationships and friendships that are situated in a shared commitment to community sustainability [32]. Stakeholder access through the partnership creates an opportunity for partners to develop organizational capital from socially complex processes. In the example above, the positive relationships that partners formed with each other are the source of their organizational capital [33], however, this capital is also associated with the specialized internal processes [16,34] or the reputation [18] of an organization.

The plan also gives the community and its partners a shared sustainability vision, which is unique to the community and the partners; this constitutes as a rare resource, especially for those organizations with non-local competitors [27]. Whistler Blackcomb, a large ski resort and partner of the Whistler2020 partnership, credits the plan with bringing the community together and argues that the resulting community cohesion provides "customers with a holistic Whistler experience" [13] (p. 13), which creates a competitive advantage for the local tourism industry and thus for Whistler Blackcomb. The 'holistic Whistler experience' example points to a resource that can benefit all partners. Here we propose a new resource, specific to the multi-stakeholder and social partnership contexts, and linked to the effectiveness and thus reputation and legitimacy of the partnership: shared capital. Shared capital is the overall sustainability image of the community and perception that the partnership's activities are contributing to community-wide sustainability. Shared capital is particularly important to partners motivated by social and environmental concerns as is the case for public and civil society partners $[9,35]$ or private sector partners that are pursuing shared value as a combined business and social responsibility strategy [36]. Also, as shared capital is linked to the legitimacy of the partnership, it is too associated with the reputational benefits that partners can expect to enjoy from their involvement in the partnership.

As the partnership progresses, partners contribute by implementing the sustainability strategies outlined in the plan, tracking progress on goal attainment, and identifying opportunities for improvement [37]. Thus, partners that actively participate in implementation have the chance to build tacit skills and capabilities for sustainability through learning-by-doing. Take, for example, Montreal's Community Sustainable Development Plan partnership that regularly arranges sustainability-focused training sessions designed to provide partners with the skills necessary to implement sustainable practices inside their organization [13]. Partners also learn from each other, as community sustainability partnerships are rich repositories of local sustainability knowledge, which is embedded in the expertise, experiences, and practices of different partner organizations [38]. For example, many partners are environmental NGOs with expertise in areas such as waste management and sustainable resource use. Such know-how can benefit other partners who want to, for instance, adopt pollution prevention strategies [39]. Thus far, we have outlined three partnership-level resources of sustainability-focused multi-stakeholder partnerships: (1) sustainability knowledge and expertise, (2) stakeholder access and (3) shared sustainability vision. We also initiated a discussion about different types of resources, including organizational, human, and shared capitals that partners stand to gain due to their involvement in a multi-stakeholder partnership. Next, we propose three different strategic capabilities that partners can use to organize further, and thus improve their capacity to capture more value from partnership-level resources. 


\subsection{Strategic Capabilities for Capturing Value from Partnership-Level Resources}

In what follows, we extend RBV's 'organized to capture value' concept to the social partnership context. We do this by proposing that three strategic capabilities, when adopted by partners of sustainability-focused multi-stakeholder partnerships, can improve the likelihood that partners will obtain competitive advantages from their involvement in the partnership. Figure 1 provides a visual summary of the relationships amongst the resources and strategic capabilities discussed in this paper.

\begin{tabular}{|c|c|c|}
\hline $\begin{array}{l}\text { Partnership-level resources } \\
\text { - Sustainability knowledge and } \\
\text { expertise (causally } \\
\text { ambiguous) } \\
\text { - Stakeholder access (socially } \\
\text { complex) } \\
\text { - Shared sustainability vision } \\
\text { (rare, community/partner } \\
\text { specific) }\end{array}$ & $\begin{array}{l}\text { Partner strategic capabilities } \\
\text { - Marketing and promotion } \\
\text { (rare, partner specific) } \\
\text { - Product stewardship (socially } \\
\text { complex) } \\
\text { - Internal implementation } \\
\text { structure (causally } \\
\text { ambiguous) }\end{array}$ & $\begin{array}{l}\text { Partner-level resources attained } \\
\text { through inimitable partnership } \\
\text { and partner processes } \\
\text { - Financial capital } \\
\text { - Human capital } \\
\text { - Organizational capital } \\
\text { - Shared capital }\end{array}$ \\
\hline
\end{tabular}

Figure 1. Partner Strategies for Capturing Value from Partnership-Level Resources.

\subsubsection{Marketing and Promotion}

There are two ways in which partner organizations can use strategic capabilities in marketing and promotion to parlay partnership-level resources into a competitive advantage: (1) leverage the partnership's sustainability image, and (2) use the partnership platform as a medium for communication. First, a shared sustainability vision can build the sustainability image of a community, which can result in reputational benefits to the implementing partners [13]. These benefits are reinforced through marketing efforts that promote partnership activities and partner involvement [13]. For example, corporate social responsibility (CSR) is a well-worn strategy used by business to bolster their reputation, and marketing is typically core to this strategy's success [40]. One such strategy common to business-nonprofit alliances is called cause-related marketing, whereby the partners implement a marketing campaign that simultaneously increases public awareness about the nonprofit partner's social cause and promotes the business partner's CSR activities related to addressing the same issue [41,42]. It is less common to consider the competitive advantage of nonprofit organizations, however, the intensified competition among organizations in this sector to secure funding, membership, and government support is increasingly incentivizing nonprofits to develop strategic capabilities in marketing and promotion $[17,43]$. As well, local governments compete with each other to attract important resources for economic development, and the reputation of the city or town can be a major contributing factor to its competitive success. For example, the City of Hamilton, a partner of the Vision 2020 partnership, "discussed the advantages of using the sustainable city premise as a sales tool, from an economic development perspective, to attract talent and business investment" [13] (p. 15). Second, simply by being a partner, organizations have increased access to local stakeholders and this can provide them with a platform to educate stakeholders about sustainability and promote their sustainability-related products, services, or programs [13]. Thus, we propose that partners who have or develop strategic capabilities in marketing and promotion will be better positioned to transform partnership-level resources into a competitive advantage.

H1. Partner marketing and promotion strategies will be positively associated with partner-level capital outcomes.

\subsubsection{Product Stewardship}

Successful product stewardship relies on the ability of an organization to effectively engage its stakeholders in a dialogue about how a product or service can and should be designed to minimize its negative impacts and maximize its positive attributes [44]. Organizations that seek to obtain information from stakeholders about the production, use and disposal of their products are positioned 
to make improvements that will matter to their stakeholders and have positive social, ecological, and economic impacts [44]. Moreover, some have argued that for an organization's product stewardship strategy to be socially accepted and viewed as legitimate the organization needs to engage with key external stakeholders, including those stakeholders with relevant environmental expertise such as environmental NGOs [45].

Many partners argue that their involvement in these partnerships is critical to their stakeholder management strategy because it strengthens their organization's relationships with its community and enhances its social license to operate $[13,46]$. Partners may be able to further operationalize the partnership-level resource, stakeholder access with strategic capabilities in product stewardship [47]. This is because stakeholder access provides partners with insight into the needs and interests of local stakeholders, which are central to successful product stewardship strategies [45]. Research on product stewardship suggests that it contributes to a competitive advantage if it helps an organization to gain exclusive access to valuable resources [27]. A case study on sustainability-focused multi-stakeholder partnerships provides an empirical example that illustrates how one partner leveraged stakeholder access into a competitive advantage through product stewardship [13]; Whistler Cooks, a small catering company and partner of the Whistler2020 community sustainability plan, beat out several much larger competitors for exclusive access to valuable contracts with the Vancouver 2010 Winter Olympics organizing committee [13]. The owner of Whistler Cooks credits this business success to the company's involvement in the Whistler2020 partnership, which influenced it to make changes that reduced the environmental impacts of its products; he argued that these changes put the company's products in direct alignment with the sustainability mandate of Vancouver Olympics and that this won them contacts because their competitors were unable to compete on this dimension [13]. Thus, it stands to reason that sustainability-focused multi-stakeholder partnerships may provide organizations with avenues to participate in productive stakeholder engagement that will inform and legitimize their product stewardship strategies. We propose that partners improve their potential for value capture from the partnership when they use information gathered from stakeholder interactions within the partnership to inform improvements or new developments of products or services. Thus we hypothesize:

\section{H2. Partner product stewardship strategies will be positively associated with partner-level capital outcomes.}

\subsubsection{Internal Implementation Structures}

A RBV proposes that organizations capture the most value when their strategic and operational management optimizes the use of its most important resources [26]. In the partnership context, partners that make internal structural changes to optimize partnership activities for value capture experience greater capital gains than partners who do not [48]. For instance, a study that examined alliances (i.e., a strategic partnership between two firms) found that partners with an organizational unit dedicated to coordinating alliance-related activities experienced higher positive stock responses than those who did not [49]. Similarly, virtual teams embedded in partner organizations were found to be an important mechanism for building relationships, trust, and understanding between partners in the business-nonprofit partnership between the Prince's Trust and Royal Bank of Scotland [50]. In another example, partners in the Earthwatch and Rio Tinto partnership made internal changes to facilitate a program called 'The Global Employee Fellowship Program', where Rio Tinto employees were sent as volunteers for Earthwatch's conservation projects [50]. The Global Employee Fellowship Program led to significant gains in Rio Tinto employees' knowledge about conservation, environmental issues and sustainable development [51].

Past research on multi-stakeholder partnerships that implement community sustainability plans found that some partners create new internal processes or structures to support the sustainability goals and activities of the partnership [10]. Such structural changes can include the creation of a new job position or operational unit that takes responsibility for the organization's commitments 
to the partnership [10]. Structural changes may also be made to support the implementation of the organization's corporate sustainability practices, which indirectly contribute to the partnership's sustainability goals [13]. For instance, when all partners reduce their greenhouse gas emissions it has a collective impact on overall air quality, and this contributes, for example, to climate change goals outlined in a community sustainability plan [3]. Partner internal implementation can simultaneously benefit the partners' and partnership's sustainability image and thus overall reputation. As illustrated in the example on local air quality, partner internal sustainability practices can scale-up progress on the partnership's sustainability goals, and thus have a greater overall impact on community-wide sustainability. When the community and the partners see that the partnership is having an impact on community sustainability it gives the partnership legitimacy, which can also result in additional reputational gains for the partners [52,53].

\section{H3. Partner internal implementation structures will be associated with partner-level capital outcomes.}

Finally, transforming partnership-level resources into resources that contribute to a partner's competitive success could require some partners to make an upfront investment into developing relevant strategic capabilities. Past research on how strategic value is created from sustainability practices, such as pollution prevention policies suggests that while these practices can require an upfront investment, the long-term returns and sustained competitive advantage make such early investments well worthwhile $[27,54]$. Figure 2 visually represents the process of partnership-level to partner-level resource transformation that occurs through partner investments into relevant strategies capabilities.

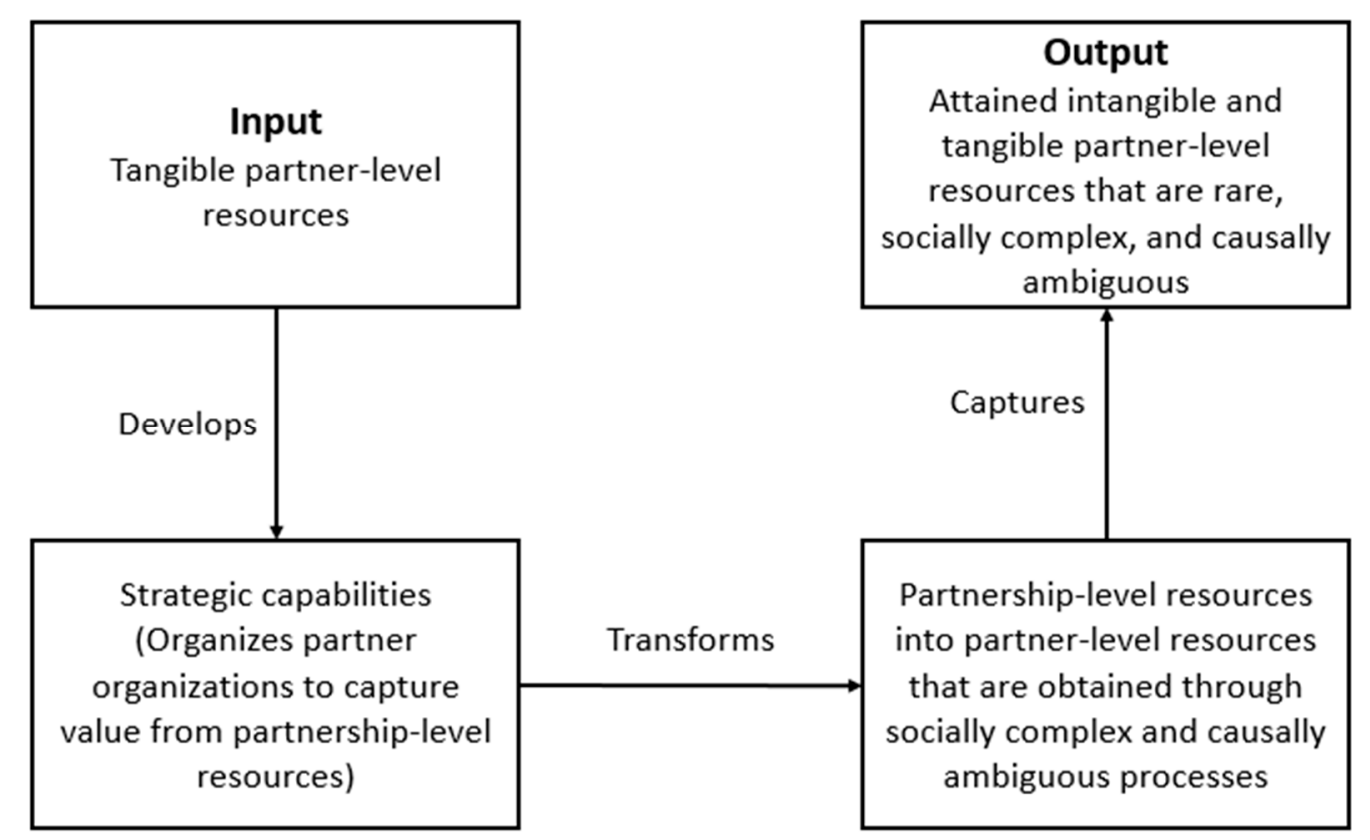

Figure 2. Resource Transformation Process.

\section{Methods}

\subsection{Sample and Procedure}

Data for this study were collected through an online survey and represent the experiences of 42 partner organizations from 15 different Canadian cities and towns that were actively implementing a community sustainability plan in partnership with local organizations. The sample includes data collected from sustainability coordinators, project coordinators, program coordinators, CEOs, and executive directors within the private $(28.6 \%)$, public $(28.6 \%)$ and civil society $(42.9 \%)$ sectors. 
Our sample includes data from partners that have been involved in the partnership from 0-2 years (28.6\%), 3-4 years (28.6\%), 5-7 years (19\%), $8-11$ years $(11.9 \%)$, and $12+$ years $(11.9 \%)$.

This study used a purposive/expert sampling method where key informants are nonrandomly selected based on predetermined criteria. To participate in this study participants needed to, (1) be the person responsible for their organization's involvement in the partnership, and the partner organization needed to be (2) part of a partnership that is actively implementing a community sustainability plan in Canada, and (3) an active member of the partnership. Based on these criteria, 15 different partnerships from 15 different Canadian cities or towns were deemed eligible to participate in this research study. Within this population, 328 partner organizations met the study's selection criteria. All partners that met the study's criteria were invited to participate in our survey; of the partners contacted, 53 returned the survey (16\%) and 42 completed the survey $(13 \%)$. The $13 \%$ response rate from the survey in this study aligns with acceptable response rates from comparable populations-that is, samples collected from nontraditional populations tend to result in lower response rates $[55,56]$. Precautions were also taken to prevent nonresponse bias; for example, survey participants were offered an incentive, the data collection time frame was over 10 months and participants were contacted through personalized e-mails and phone calls. Surveys were also available in Canada's two official languages, French and English.

\subsection{Measures}

The constructs developed for this study were informed by prior case study research on Canadian LA21 partnerships and literature review $[10,13]$. To assess the content validity of our survey measures, we sent the survey for review to academics and professionals with expertise in the areas of local sustainability and cross-sector partnerships [57]. For example, the survey was reviewed by the director and manager of Local Governments for Sustainability Canada (ICLEI). ICLEI is a nongovernmental organization with a mandate to support local authorities with meeting their sustainable development goals. The final survey included measures for three independent variables, (1) marketing and promotion, (2) product stewardship, and (3) internal implementation structure, and four dependent variables, (1) financial, (2) human, (3) organizational and (4) shared capital. All seven constructs were measured on five-point Likert scales $(1=$ disagree to $5=$ agree). Internal consistency for each measure was assessed using Cronbach's alpha $(\alpha)$, whereby $\alpha$ values $>0.70$ indicates good internal consistency [58].

\subsubsection{Marketing and Promotion (Marketing)}

A two-item scale measured partner organization marketing and promotion efforts that resulted from their involvement in implementing the community sustainability plan. The survey questions for this construct included, as a result of partnering in the implementation of your community's sustainability plan your organization has (1) increased its publicity efforts and (2) increased its marketing. The Cronbach's $\alpha$ for this measure is 0.91 , indicating internal consistency for this measure.

\subsubsection{Product Stewardship (Stewardship)}

A two-item scale measured changes to the partner organizations product and service offering resulting from their involvement in implementing the community sustainability plan. Survey questions for this construct included, for example, as a result of being involved in implementing your community sustainability plan your organization has developed new products/services. The Cronbach's $\alpha$ for this measure is 0.92 , indicating internal consistency for this measure.

\subsubsection{Internal Implementation Structure (Structure)}

A three-item scale measured the comprehensiveness of partner internal implementation structures that support sustainability initiatives and efforts. Survey questions for this construct included, for example, your organization has created new sustainability-related job positions and your 
organization has created new sustainability-related processes (e.g., monitoring and reporting, communication, etc.). The Cronbach's $\alpha$ for this measure is 0.89 , indicating internal consistency for this measure.

\subsubsection{Financial Capital (Financial)}

A four-item scale measured the degree to which participating in the implementation of a community sustainability plan resulted in positive financial outcomes for partners. Survey respondents were asked questions such as, as a result of being involved in implementing your community sustainability plan (1) your organization has gained additional funding opportunities (2) your organization has experienced cost savings, and (3) your organization has improved its financial performance. Cronbach's $\alpha$ value is 0.89 .

\subsubsection{Human Capital (Human)}

This construct used a five-item scale to measure the degree to which partners experience increased human capital, particularly the development of competencies related to sustainability. Sample questions for this measure include, as a result of being involved in implementing your community's sustainability plan (1) employee awareness of sustainability has improved, (2) senior management's understanding of sustainability has improved and (3) your organization has gained new knowledge about the activities of other organizations. Cronbach's $\alpha$ value is 0.86 .

\subsubsection{Organizational Capital (Organizational)}

A four-item scale was used to measure the degree to which partners experienced improvements in organizational capital, such as reputation and legitimacy, due to their participation in implementing a community sustainability plan. Sample questions for this measure include, as a result of being involved in implementing your community's sustainability plan (1) your organization has increased its overall reputation, (2) your organization has improved its relationship with the community, and (3) your organization has improved its relationship with other organizations in the partnership. Cronbach's $\alpha$ value is 0.93 .

\subsubsection{Shared Capital (Shared)}

A four-item scale was used to measure the degree to which partners felt that their involvement in the community sustainability plan contributed to overall sustainability improvements for the community. Sample questions for this measure include, as a result of being involved in implementing your community's sustainability plan (1) your organization has positively influenced sustainability within your community, (2) your organization has helped to reach the goals set in the community sustainability plan, and (3) your organization has made progress towards its sustainability goals. Cronbach's $\alpha$ value is 0.85 .

\subsubsection{Control Variables}

Two variables were included to control for possible alternative explanations for partner capital outcomes, duration and organization type. First, duration or length of time that the organization has been a partner in the partnership has the potential to both positively and negatively affect the predictors and outcomes in this study [48]. For example, over time the partners have the chance to develop their relationships and processes for implementation [59]. However, extended involvement in the partnership can also result in partner fatigue, which has a negative influence on outcomes, such as relationship building and progress made on sustainability goals [60]. We measured the length of the partnership by asking the partners to indicate the number of years that they had been involved in the partnership by selecting from a drop-down menu. The drop-down menu included the following categories; 0-2 years, 3-4 years, 5-7 years, $8-11$ years, and $12+$ years. For our analysis, we created a 
dummy variable for duration, where partners involved in the partnership for under seven years were set to 0 , and partners involved for eight-plus years were coded as 1 .

Second, multi-stakeholder partnerships examined in this study include partners from private, public, and civil society sectors. Organizations from different sectors have varying levels of capacity and different motives for being involved in a voluntary social partnership [61]. These differences could have the propensity to influence their capacity to create internal structures for implementing sustainability strategies. For example, small civil society organizations are less likely than partners from the private and public sectors to have funds to support a sustainability department or full-time sustainability coordinator. It could also influence where the organization invests its resources for capturing value, for example, partners from the private sector may spend more than partners from other sectors on publicizing their involvement in the social partnership to maximize the reputational benefits. We measured the organization type by asking the partners to select the type of organization that they belong to from a drop-down menu. We then formed three classes of organizations by creating dummy variables for organizations in each of the three sectors: private, public, and civil society. For our regression analyses, we set civil society to zero in all models.

In terms of the sector groupings, it is important to note that we grouped university partner organizations in the private instead of public sector category. Most universities in Canada are technically classified as public sector organizations, however, we added them to the private sector category because universities in Canada behave more like private sector than public or civil society sector partners in LA21 partnerships. Universities tend to adopt sustainable practices based on the business case for these practices. Consequently, they join Local Agenda partnerships as part of their stakeholder engagement or product stewardship strategies which are aimed at attracting students and highly skilled employees, as well as maintaining their social license to operate [13]. In other words, university like business partners, are interested in partner outcomes that will build their capacity to meet the social responsibility demands and expectations of their key stakeholders in order to improve their reputation and take advantage of growth opportunities [9]. Public sector partners, on the other hand, have a primary interest in using the partnership to gather public support for and help with addressing community-wide sustainability issues under their jurisdiction but are too complex to tackle alone [9].

\subsection{Analysis}

We systematically examined the data for missing values, unengaged responses and normality. Skewness and kurtosis values with absolute value less than 3.0 were used to assess the normality of the data for each variable [62]. According to these statistical tests, this dataset shows a normal distribution. We also used variance inflation factors (VIF) from regression analyses to assess multicollinearity amongst independent variables: product stewardship (VIF = 1.37), marketing and promotion (1.41), and internal implementation structure (1.48). All VIF values are below the threshold $(<5)$ indicating no evidence for multicollinearity [63]. A bivariate analysis was adopted to identify the correlations among variables [64]. Hypotheses 1, 2, and 3 were tested using regression models.

\section{Results}

The descriptive statistics and results of the Pearson correlation matrix are reported in Table 1.

Table 2 summarizes the descriptive statistics for the control variables, comparing the means and standard deviations of the study variables by organization type and duration. The descriptive statistics reported in Table 2 indicate that on average public sector partners invest more than partners from other sectors on marketing, as well as, on internal implementation structures, whereas private sector partners invest the most of all partners on product stewardship. Surprisingly private sector partners invest the least on marketing, and as expected civil society partners invest less than other partner types on internal implementation structures. Overall, public sector partners reported the most gains in financial, 
human, and organizational capital as a result of their involvement in the partnership, whereas civil society partners reported the fewest gains in the financial and organizational outcome categories.

Table 1. Descriptive Statistics and Pearson Correlation Matrix ${ }^{\dagger}$.

\begin{tabular}{|c|c|c|c|c|c|c|c|c|}
\hline & $\mathbf{M}$ & SD & 1 & 2 & 3 & 4 & 5 & 6 \\
\hline 1. Marketing & 3.50 & 1.13 & 1 & & & & & \\
\hline 2. Stewardship & 2.96 & 1.21 & $0.427^{* *}$ & 1 & & & & \\
\hline 3. Structure & 2.80 & 1.37 & $0.491^{* *}$ & $0.469 * *$ & 1 & & & \\
\hline 4. Financial & 2.80 & 1.13 & $0.630^{* *}$ & $0.651^{* *}$ & $0.520^{* *}$ & 1 & & \\
\hline 5. Human & 3.84 & 0.86 & $0.653 * *$ & $0.404^{* *}$ & $0.630 * *$ & $0.500 * *$ & 1 & \\
\hline 6. Organizational & 3.85 & 0.92 & $0.595^{* *}$ & 0.560 ** & $0.542^{* *}$ & $0.629 * *$ & $0.725 * *$ & 1 \\
\hline 7. Shared & 3.80 & 0.88 & $0.407^{* *}$ & 0.394 * & $0.582 * *$ & $0.453^{* *}$ & $0.619 * *$ & $0.665^{* *}$ \\
\hline
\end{tabular}

Table 2. Descriptive Statistics for Organization Type and Duration.

\begin{tabular}{|c|c|c|c|c|c|c|c|c|c|c|}
\hline & \multicolumn{2}{|c|}{ Private } & \multicolumn{2}{|c|}{ Public } & \multicolumn{2}{|c|}{ Civil Society } & \multicolumn{2}{|c|}{$\begin{array}{c}\text { Partner for } \\
\text { under } 7 \text { Years }\end{array}$} & \multicolumn{2}{|c|}{$\begin{array}{l}\text { Partner for } \\
7+\text { Years }\end{array}$} \\
\hline & M & SD & $\mathrm{M}$ & SD & M & SD & M & SD & $\mathrm{M}$ & SD \\
\hline Marketing & 3.17 & 1.21 & 3.83 & 0.69 & 3.44 & 1.28 & 3.43 & 1.24 & 3.60 & 0.66 \\
\hline Stewardship & 3.16 & 1.03 & 2.96 & 1.16 & 2.83 & 1.40 & 3.00 & 1.16 & 2.85 & 1.43 \\
\hline Structure & 2.86 & 1.39 & 3.26 & 1.25 & 2.38 & 1.38 & 2.70 & 1.40 & 3.00 & 1.31 \\
\hline Financial & 2.81 & 0.83 & 3.21 & 1.24 & 2.44 & 1.17 & 2.74 & 1.18 & 2.82 & 1.01 \\
\hline Human & 3.72 & 0.81 & 4.10 & 0.47 & 3.76 & 1.07 & 3.73 & 0.92 & 4.20 & 0.47 \\
\hline Organizational & 3.88 & 0.68 & 4.13 & 0.64 & 3.67 & 1.18 & 3.72 & 0.10 & 4.30 & 0.39 \\
\hline Shared & 3.97 & 0.98 & 3.94 & 0.79 & 3.57 & 1.12 & 3.55 & 0.97 & 4.57 & 0.19 \\
\hline
\end{tabular}

Duration of partner involvement in implementing the community sustainability plan appears to have the most impact on shared capital, whereby long-term partners reported having more influence on progress made on sustainability goals. The descriptive statistics reported in Table 2 also indicate, that on average, long-term partners experience slightly higher levels of human and organizational capital.

\section{Hypothesis Testing}

The following are the results of our regression analyses. We conducted four regression models to examine the relationships between our independent variables and outcome variables. We found partial support for all three of our hypotheses, in that, each strategic capability is a predictor of at least one capital. However, not all capabilities are associated with all partner capital outcomes. Broadly, we found that the best predictors of financial and organizational capitals are product stewardship and marketing, whereas human capital is predicted by marketing and structure, and shared capital has the strongest association with structure.

The results of our regression model for financial capital, reported in Table 3, found that independent variables, stewardship and marketing had positive associations with financial capital, ( $B=0.41, p=0.001$ and $B=0.38, p=0.005$, respectively). These findings suggest that financial benefits to partners may be linked to the product stewardship and marketing efforts made by the partner organizations as a result of their involvement in implementing a community sustainability plan.

Our results found that marketing and structure were the best predictors of human capital in our regression model ( $B=0.32, p=0.004$ and $B=0.24, p=0.010$, respectively). These findings indicate an association between partner learning/capacity building, especially in the area of sustainability and partner organization investments in marketing and internal structures for implementing sustainability-related strategies. However, our model did not find support for a relationship between product stewardship and human capital. Also, neither organization type nor duration had an impact on gains in human capital. The results of our regression model for human capital are summarized in Table 4. 
Table 3. Results of Regression Model for Financial Capital.

\begin{tabular}{cccc}
\hline & $\boldsymbol{B}$ & SE B & $\boldsymbol{\beta}^{\dagger}$ \\
\hline Constant & -0.20 & 0.43 & \\
Marketing & $0.38^{* *}$ & 0.13 & 0.38 \\
Stewardship & $0.41^{* * *}$ & 0.12 & 0.45 \\
Structure & 0.06 & 0.11 & 0.62 \\
Duration & 0.07 & 0.28 & 0.03 \\
Private sector & 0.30 & 0.29 & 0.31 \\
Public sector & 0.52 & 0.29 & 0.08 \\
\hline \multicolumn{3}{c}{ Adjusted $\mathrm{R}^{2}=0.56^{* *} p<0.01{ }^{* * *} p<0.001$} \\
\hline \multicolumn{3}{c}{ Standardized coefficient } \\
\hline
\end{tabular}

Table 4. Results of Regression Model for Human Capital.

\begin{tabular}{cccc}
\hline & $\boldsymbol{B}$ & $\boldsymbol{S E} \boldsymbol{B}$ & $\boldsymbol{\beta}^{\boldsymbol{}}$ \\
\hline Constant & 1.90 & 0.34 & \\
Marketing & $0.32^{* *}$ & 0.10 & 0.41 \\
Stewardship & 0.05 & 0.09 & 0.07 \\
Structure & $0.24^{* *}$ & 0.09 & 0.38 \\
Duration & 0.37 & 0.22 & 0.19 \\
Private sector & -0.13 & 0.23 & -0.07 \\
Public sector & 0.02 & 0.23 & 0.01 \\
\hline \multicolumn{3}{c}{ Adjusted $\mathrm{R}^{2}=0.52{ }^{* *} p<0.01$} \\
\hline
\end{tabular}

We found positive and statistically significant associations between the outcome variable, organizational capital and predictors stewardship and marketing $(B=0.27, p=0.011$ and $B=0.27$, $p=0.020$, respectively). These results, reported in Table 5, indicate that similar to the financial capital outcome, organizational capital or improvements in a partner organization's reputation and stakeholder relationships is linked to the product stewardship and marketing efforts of that partner. We did not find a relationship between structure and organizational capital. However, we did find a positive and statistically significant relationship between organizational capital and duration, which suggests that organizational capital builds over time.

Table 5. Results of Regression Model for Organizational Capital.

\begin{tabular}{cccc}
\hline & $\boldsymbol{B}$ & $\boldsymbol{S E} \boldsymbol{B}$ & $\boldsymbol{\beta}^{\dagger}$ \\
\hline Constant & 1.61 & 0.37 & \\
Marketing & $0.27^{*}$ & 0.11 & 0.33 \\
Stewardship & $0.27^{* *}$ & 0.10 & 0.36 \\
Structure & 0.11 & 0.09 & 0.16 \\
Duration & $0.56^{*}$ & 0.24 & 0.26 \\
Private sector & 0.08 & 0.25 & 0.04 \\
Public sector & 0.26 & 0.25 & 0.13 \\
\hline \multicolumn{3}{c}{ Adjusted $\mathrm{R}^{2}=0.50{ }^{*}{ }^{*} p<0.05,{ }^{* *} p<0.01$} \\
\hline
\end{tabular}

For the outcome variable shared capital, we found that structure $(B=0.24, p=0.016)$ was the strongest predictor when compared to the other independent variables in our regression model. These findings suggest that organizations that invest in internal structural supports for sustainability will make more significant contributions to achieving the partnership's sustainability goals. The results of our regression model for shared capital, reported in Table 6, also show that duration was overall 
the strongest predictor of progress made on sustainability goals $(B=0.80, p=0.003)$. This finding suggests that time spent in the partnership has a positive impact on partner contributions to sustainability progress.

Table 6. Results of Regression Model for Shared Capital.

\begin{tabular}{cccc}
\hline & $\boldsymbol{B}$ & SE $\boldsymbol{B}$ & $\boldsymbol{\beta}^{+}$ \\
\hline Constant & 2.17 & 0.38 & \\
Marketing & 0.08 & 0.11 & 0.10 \\
Stewardship & 0.14 & 0.10 & 0.19 \\
Structure & $0.24^{*}$ & 0.10 & 0.38 \\
Duration & $0.80^{* *}$ & 0.25 & 0.39 \\
Private sector & 0.08 & 0.26 & 0.04 \\
Public sector & 0.24 & 0.26 & 0.13 \\
\hline \multicolumn{3}{c}{ Adjusted ${ }^{2}=0.44 ;^{*} p<0.05,{ }^{* *} p<0.01$} \\
\hline
\end{tabular}

\section{Discussion}

Partnership researchers have identified the need for a deeper understanding of implementation and outcomes at the partner level (see $[10,15,48,49,53,65,66])$. Moreover, the need to understand the contributing factors of partner outcomes is important in addressing one of the critical challenges to success in multi-stakeholder partnerships, which is how to maintain ongoing partner engagement $[5,21]$. This study aims to address this research gap and advance what is known about the outcomes of multi-stakeholder partnerships by examining the impacts of implementation strategies on resource outcomes at the partner level. Our findings show that value capture and strategic capabilities are linked and that different partner strategies are associated with different partner outcomes. Our findings also indicate that the number of years an organization has been a partner contributes to resources it can expect to extract from its partnership activities. This research contributes to the multi-stakeholder partnership literature by helping to predict which partners will succeed in capturing value for their organization based on the strategic capabilities that they develop and employ during their involvement in the partnership. This study also contributes to sustainable development literature by demonstrating how community sustainability plan implementation can be scaled up through multi-stakeholder partnerships when the partners contribute by pursuing their own sustainability goals, impacting shared capital outcomes and indirectly contributing to progress on community-wide sustainability goals.

\subsection{Partner-Level Strategic Capabilities and Resource Outcomes}

This research shows the importance of strategic capabilities to partner capital gains and suggests that partner choices about which capabilities to invest in have implications for their ability to capture certain types of value from the partnership. First, our findings that the marketing and promotion variable is positively associated with both financial and organizational capital gains aligns with past research on marketing, organization reputation, and financial outcomes. For example, in the private sector, marketing is essential to gaining the reputational, and thus financial benefits from CSR activities [40]. Likewise, nonprofit organizations are increasingly investing in marketing strategies to improve the reputation and visibility of their programs or services, so that they can compete with other nonprofits for access to funding opportunities [43]. Somewhat surprisingly, of the three strategic capabilities compared in this study, marketing and promotion was the best predictor of improved human capital. One potential explanation for this finding could be that the partners in our study use marketing and promotion strategies to influence stakeholder preferences and behaviours through educational campaigns that promote the importance and merits of sustainable practices. Cause-related marketing strategies, for example, are commonly implemented through 
social partnerships to simultaneously promote a social cause and a company's CSR activities [41]; it is possible that partners could, through their involvement in developing and implementing this type of marketing campaign, build their organization's knowledge about the focal social issue. We did not find support for an association between marketing and promotion and shared capital; indicating that, while effective at generating positive outcomes for partners, this capability is not directly related to the achievement of the partnership's sustainability goals.

Second, our assessment of product stewardship found that this capability predicts positive gains in financial and organizational capital. Past research on product stewardship strategies for sustained competitive advantage argues that stakeholder engagement is critical to the long-term success of these strategies [44,47]. By merely being involved in an LA21 partnership, partners increase their access to wide range of local organizations and community members that they would be unlikely to reach using traditional stakeholder engagement strategies, such as information sharing or consultation [13,67]. Our findings indicate that partners who take advantage of this broadened access to local stakeholders by obtaining informational inputs for product and service changes or new designs are strategically positioned to increase their legitimacy and monetary gains.

Finally, our finding that partners who implement the goals outlined in their community sustainability plan by making internal structural changes to their organization, such as hiring a sustainability coordinator or creating new sustainability-related processes report the most shared capital. This indicates that progress on community-wide sustainability goals is linked to sustainable practices implemented internally by partners. Further, the finding that the number of years a partner is involved in the partnership is the strongest predictor of shared capital suggests that the ongoing engagement of long-term partners is essential to implementing the plan goals and achieving community-wide sustainability through the partnership mechanism.

\subsection{Implications for Research}

This study extends the multi-stakeholder partnership literature in two ways. First, it unpacked and examined partner-level implementation strategies by identifying strategic capabilities that contribute to the capacity of partners to capture value from the partnership. Previous studies on the processes that drive outcomes in partnerships have focused on partner-level characteristics or relationships [17,48-50] or partnership-level implementation strategies [5]. By studying partner strategic capabilities, the present study provides insight into how partners can themselves organize to capture value from their partnership activities. For example, we use concepts from RBV to demonstrate how partners can transform tangible resource inputs, such as employee time spend developing stakeholder relationships through partner activities, into intangible resources, such as stakeholder insights that inform product stewardship strategies. In other words, from a resource-based perspective partners are organized to capture value from partnership-level resources when they develop strategic capabilities that help them to operationalize causally ambiguous or socially complex resources into a competitive advantage. Moreover, the notion of investment to return from partnerships aligns with the literature on cross-sector social partnerships that posits greater investment in the partnership results in greater returns $[16,42,68,69]$. These insights might be particularly relevant to understanding how multi-stakeholder, specifically LA21 partnerships, can better maintain partner engagement over time, especially given the engagement challenges that this partnership form tends to experience $[4,6]$.

Second, in using a survey to collect the data for this study, we answer calls for more methodological variety in cross-sector social partnerships research $[7,70,71]$. The survey method was necessary for this study as it gave us the opportunity to ask directed quantifiable questions to targeted participants. This type of detailed information would not be possible through a database, which would need to use proxies to assess partner outcomes, for example, the number of patents is a standard proxy used to measure partnership innovation outcomes. 


\subsection{Implications for Practice}

These research findings have implications for partners and for organizations considering joining sustainability-focused multi-stakeholder partnerships. Local government partners or partners responsible for managing partner engagement might identify ways in which they can help partner organizations to develop capabilities in the strategies discussed in this paper. For instance, facilitators could organize training or consultation sessions that help partners choose their sustainability goals and identify the internal structural changes needed to reach those goals [60]. This kind of support from facilitators might reduce barriers for partners who are challenged by the initial upfront investment required to build capacity in some strategic areas $[5,21,72]$. The aim of these partnerships is to address complex societal challenges by leveraging the insights and resources of many different stakeholders [15], and so it is essential that partnership facilitators or secretariat members understand and can articulate the organizational benefits of the partnership to partners [8]. In particular, making sure that private sector partners understand the 'business case' for their involvement, such as improved reputation or growth opportunities, is necessary to ensure that the partnership has the right composition of resources and can be sustained over time [9].

For all partners, these research findings indicate that joining a multi-stakeholder partnership might not be enough to capture value from the partnership. Partners might consider developing certain strategic capabilities depending on their organization's goals for being involved in the partnership. Public sector partners, for example, tend to participate in LA21 partnerships to get help from local organizations with addressing complex sustainability issues that they are unable to tackle alone [9]. Our results suggest that partners from the public sector should invest in internal implementation structures, which were most strongly associated with making progress on community-wide sustainability goals. In contrast, private sector partner involvement is motivated by the desire to meet the CSR expectations of their stakeholders or develop new products and services that will expand their business $[9,13]$. The findings from our study indicate that private sector partners might consider using the partnership to build capacity in product stewardship as this strategy had the most impact on positive financial outcomes. The civil society sector includes partners from the most diverse group of organizations [73], and so the best strategy for value capture will depend on the organization and its goals for partnering. In general, organizations that want to use sustainability strategies to gain a competitive advantage should consider joining or forming a multi-stakeholder partnership with a sustainability focus. In particular, organizations that want to adopt product stewardship strategies stand the benefit from the stakeholder access afforded to them by being involved in a multi-stakeholder partnership $[27,54]$.

\subsection{Areas for Future Research and Limitations}

Partnership value creation is a function of many variables both inside the partnership (e.g., implementation structure, governance structure, partners involved) and outside the partnership (e.g., environmental, political, and economic context in which the partnership resides). A focus on implementation structure alone offers various avenues for research [74] especially as the partnership increases in size and becomes more complex [21]. This study considered one dimension of implementation, partner strategic capabilities for value capture. There are many other important aspects of implementation at the partnership level such as monitoring and reporting systems [75], accountability systems [76], and communication systems [77]. Each system could be individually and collectively tested for their impact on value creation for partners and partnership beneficiaries (e.g., the environment or community).

An international study on community sustainability-focused multi-stakeholder partnerships is needed to assess the generalizability of the present study's findings to contexts outside of Canada. This is a viable avenue for future research as the partnerships in this study exist around the world and share many contextual and historical similarities due to the influence of the United Nations on community sustainability planning $[5,78]$. Another challenge to the generalizability of our findings 
is the possibility of response bias, whereby the partners who responded to our survey may be more engaged in the partnership than those partners who did not participate in this study. Both the small number of participants that were eligible to participate in our study and participant self-selection are limitations that restrict the generalizability of our findings.

While this study examined predictors of partner capital outcomes, it did not examine how these outcomes influence or reinforce each other. Previous research indicates a relationship between social and human capital in partnerships [79]. Thus it is possible that partners further increase their sustainability knowledge through their interactions and relationships formed with other sustainability-focused organizations participating in the partnership. Moreover, partner capital outcomes could also influence the strategic capabilities studied here. For example, increased sustainability knowledge could subsequently impact a partner's capacity to develop internal sustainable practices, thus impacting shared capital outcomes and ultimately progress made on community-wide sustainability.

Additionally, partners who implement their organization's sustainability goals through internal implementation structures are learning-by-doing and thus are likely building tacit skills in sustainable practices. Future research might consider further unpacking these relationships to extend understanding of the dynamics among different types of partner capitals, strategic capabilities, and partnership capacity to reach community-wide sustainability goals. Also, this study did not examine the impacts of partner existing strategic capabilities on outcomes. Past research has considered how a firm's existing strategic capabilities can contribute to the likelihood that its sustainable practices will translate into a competitive advantage [27], researchers interested in extending this work could investigate the impacts of partner pre-existing strategic capabilities on outcomes in the context of multi-stakeholder partnerships.

Author Contributions: Conceptualization, including formulation of research goals and aims for this manuscript was led by A.M. and A.C. with input from M.M.S. and L.H. The methodological design involved contributions from all authors. Investigation and formal analysis activities, as well as writing for this manuscript including original draft preparation and review and editing was conducted by A.M. with guidance from A.C., L.H. and M.M.S. Funding acquisition for this project was provided by A.C. and A.M.

Funding: This research was funded by the Centre for International Governance Innovation (CIGI), and the article processing charge (APC) was funded by the Dhillon School of Business and the School of Environment, Enterprise, and Development.

Conflicts of Interest: The authors declare no conflict of interest.

\section{References}

1. Reed, A.M.; Reed, D. Partnerships for development: Four models of business involvement. J. Bus. Ethics 2008, 90 (Suppl. S1), 3. [CrossRef]

2. Brouwer, J.; Woodhill, A.; Hemmati, M.; Verhoosel, K.; van Vugt, S. The MSP Guide; Practical Action Publishing Ltd.: Warwickshire, UK, 2016.

3. MacDonald, A.; Clarke, A.; Huang, L.; Roseland, M.; Seitanidi, M.M. Multi-stakeholder partnerships (SDG\# 17) as a means of achieving sustainable communities and cities (SDG\# 11). In Handbook of Sustainability Science and Research; Springer: Cham, Switzerland, 2018; pp. 193-209.

4. Mehta, P. Local Agenda 21: Practical experiences and emerging issues from the South. Environ. Impact Assess. Rev. 1996, 16, 309-320. [CrossRef]

5. MacDonald, A.; Clarke, A.; Huang, L. Multi-stakeholder partnerships for sustainability: Designing decision-making processes for partnership capacity. J. Bus. Ethics 2018, 1-18. [CrossRef]

6. Mercer, D.; Jotkowitz, B. Local Agenda 21 and barriers to sustainability at the local government level in Victoria, Australia. Aust. Geogr. 2000, 31, 163-181. [CrossRef]

7. Selsky, J.W.; Parker, B. Cross-sector partnerships to address social issues: Challenges to theory and practice. J. Manag. 2005, 31, 849-873. [CrossRef]

8. Caplan, K. The Purist's Partnership: Debunking the Terminology of Partnerships; The Copenhagen Centre: Copenhagen, Denmark, 2003; pp. 31-35. 
9. Overseas Development Institute; Foundation for Development Cooperation. Multi Stakeholder Partnerships Issue Paper; Global Knowledge Partnership: Kuala Lumpur, Malaysia, 2003.

10. Clarke, A. Key structural features for collaborative strategy implementation: A study of sustainable development/Local Agenda 21 collaborations. Manag. Avenir 2011, 153-171. [CrossRef]

11. McHugh, M.C.; Harvey, J.B.; Aseyev, D.; Alexander, J.A.; Beich, J.; Scanlon, D.P. Approaches to improving healthcare delivery by multistakeholder alliances. Am. J. Manag. Care 2012, 18, S156-S162. [PubMed]

12. Kihl, L.A.; Tainsky, S.; Babiak, K.; Bang, H. Evaluation of a cross-sector community initiative partnership: Delivering a local sport program. Eval. Program Plan. 2014, 44, 36-47. [CrossRef] [PubMed]

13. Clarke, A.; MacDonald, A. Outcomes to partners in multistakeholder cross-sector partnerships a resource-based view. Bus. Soc. 2019, 58, 298-332. [CrossRef]

14. Rok, A.; Kuhn, S. Local Sustainability 2012: Taking Stock and Moving Forward; International Council for Local Environmental Initiatives_Local Governments for Sustainability: Bonn, Germany, 2012.

15. Clarke, A.; Crane, A. Cross-Sector Partnerships for Systemic Change: Systematized Literature Review and Agenda for Further Research. J. Bus. Ethics 2018, 150, 303-313. [CrossRef]

16. Hardy, C.; Phillips, N.; Lawrence, T.B. Resources, knowledge and influence: The organizational effects of interorganizational collaboration. J. Manag. Stud. 2003, 40, 321-347. [CrossRef]

17. Arya, B.; Lin, Z. Understanding collaboration outcomes from an extended resource-based view perspective: The roles of organizational characteristics, partner attributes, and network structures. J. Manag. 2007, 33, 697-723. [CrossRef]

18. Muñoz-Erickson, T.A.; Aguilar-González, B.; Loeser, M.R.R.; Sisk, T.D. A framework to evaluate ecological and social outcomes of collaborative management: Lessons from implementation with a Northern Arizona collaborative group. Environ. Manag. 2009, 45, 132-144. [CrossRef] [PubMed]

19. Vurro, C.; Dacin, M.T.; Perrini, F. Institutional antecedents of partnering for social change: How institutional logics shape cross-sector social partnerships. J. Bus. Ethics 2011, 94, 39-53. [CrossRef]

20. Worthington, I.; Patton, D.; Lindley, I. Local authorities, business and LA21: A study of East Midlands sustainable development partnerships. Local Gov. Stud. 2003, 29, 91-110. [CrossRef]

21. Babiak, K.; Thibault, L. Challenges in multiple cross-sector partnerships. Nonprofit Volunt. Sect. Q. 2009, 38, 117-143. [CrossRef]

22. Barney, J. Firm resources and sustained competitive advantage. J. Manag. 1991, 17, 99-120. [CrossRef]

23. Penrose, E.T. The Theory of the Growth of the Firm; Oxford University Press: New York, NY, USA, 1959.

24. Wernerfelt, B. A resource-based view of the firm. Strateg. Manag. J. 1984, 5, 171-180. [CrossRef]

25. Acedo, F.J.; Barroso, C.; Galan, J.L. The resource-based theory: Dissemination and main trends. Strateg. Manag. J. 2006, 27, 621-636. [CrossRef]

26. Barney, J.B. Looking inside for competitive advantage. Acad. Manag. Exec. 1995, 9, 49-61. [CrossRef]

27. Hart, S.L. A natural-resource-based view of the firm. Acad. Manag. Rev. 1995, 20,969-1014. [CrossRef]

28. Teece, D.; Pisano, G. The dynamic capabilities of firms: An introduction. Ind. Corp. Chang. 1994, 3, 537-556. [CrossRef]

29. Teece, D.J. Profiting from technological innovation: Implications for integration, collaboration, licensing and public policy. Res. Policy 1986, 15, 285-305. [CrossRef]

30. Das, T.K.; Teng, B.-S. A resource-based theory of strategic alliances. J. Manag. 2000, 26, 31-61. [CrossRef]

31. Grant, R.M. Toward a knowledge-based theory of the firm. Strateg. Manag. J. 1996, 17, 109-122. [CrossRef]

32. Worley, C.G.; Mirvis, P.H. Studying networks and partnerships for sustainability: Lessons learned. In Building Networks and Partnerships; Emerald Group Publishing Limited: Bingley, UK, 2013; Volume 3, pp. 261-291.

33. Den Hond, F.; de Bakker, F.G.; Doh, J. What prompts companies to collaboration with NGOs? Recent evidence from the Netherlands. Bus. Soc. 2015, 54, 187-228. [CrossRef]

34. Bryson, J.M.; Bromiley, P. Critical factors affecting the planning and implementation of major projects. Strateg. Manag. J. 1993, 14, 319-337. [CrossRef]

35. Koontz, T.M.; Thomas, C.W. Measuring the performance of public-private partnerships: A systematic method for distinguishing outputs from outcomes. Public Perform. Manag. Rev. 2012, 35, 769-786. [CrossRef]

36. Porter, M.E.; Kramer, M.R. The big idea: Creating shared value. Harv. Bus. Rev. 2011, 89, 2.

37. Kelly, R.; Moles, R. The development of Local Agenda 21 in the Mid-West Region of Ireland: A case study in interactive research and indicator development. J. Environ. Plan. Manag. 2002, 45, 889-912. [CrossRef] 
38. Bryson, J.M.; Crosby, B.C.; Stone, M.M. The design and implementation of cross-sector collaborations: Propositions from the literature. Public Adm. Rev. 2006, 66, 44-55. [CrossRef]

39. Jörby, S.A. Local Agenda 21 in Four Swedish municipalities: A tool towards sustainability? J. Environ. Plan. Manag. 2002, 45, 219-244. [CrossRef]

40. Yaziji, M. Turning gadflies into allies. Harv. Bus. Rev. 2004, 82, 110-115.

41. Liu, G.; Ko, W.-W. An analysis of cause-related marketing implementation strategies through social alliance: Partnership conditions and strategic objectives. J. Bus. Ethics 2011, 100, 253-281. [CrossRef]

42. Peloza, J.; Ye, C. How social partnerships build brands. In Social Partnerships and Responsible Business; Seitanidi, M.M., Crane, A., Eds.; Routledge: New York, NY, USA, 2014; pp. 191-204.

43. Foster, M.K.; Meinhard, A.G. A contingency view of the responses of voluntary social service organizations in Ontario to government cutbacks. Can. J. Adm. Sci. 2002, 19, 27-41. [CrossRef]

44. Hart, S.L.; Milstein, M.B. Creating sustainable value. Acad. Manag. Perspect. 2003, 17, 56-67. [CrossRef]

45. Westley, F.; Vredenburg, H. Strategic bridging: The collaboration between environmentalists and business in the marketing of green products. J. Appl. Behav. Sci. 1991, 27, 65-90. [CrossRef]

46. Clarke, A.; MacDonald, A.; Ordonez-Ponce, E. Implementing community sustainability strategies through cross-sector partnerships: Value creation for and by businesses. In Business Strategies for Sustainability; Routledge: London, UK, 2018; pp. 402-416.

47. Schuster, T.; Holtbrügge, D. Benefits of cross-sector partnerships in markets at the base of the pyramid. Bus. Strategy Environ. 2014, 23, 188-203. [CrossRef]

48. Schreiner, M.; Kale, P.; Corsten, D. What really is alliance management capability and how does it impact alliance outcomes and success? Strateg. Manag. J. 2009, 30, 1395-1419. [CrossRef]

49. Kale, P.; Dyer, J.H.; Singh, H. Alliance capability, stock market response, and long-term alliance success: The role of the alliance function. Strateg. Manag. J. 2002, 23, 747-767. [CrossRef]

50. Seitanidi, M.M.; Crane, A. Implementing CSR through partnerships: Understanding the selection, design and institutionalisation of nonprofit-business partnerships. J. Bus. Ethics 2009, 85, 413-429. [CrossRef]

51. Seitanidi, M.M. The Politics of Partnerships: A Critical Examination of Nonprofit-Business Partnerships; Springer: London, UK, 2010.

52. Cropper, S. Collaborative working and the issue of sustainability. In Creating Collaborative Advantage; SAGE Publications: London, UK, 1996; pp. 81-100.

53. Koontz, T.M.; Thomas, C.W. What do we know and need to know about the environmental outcomes of collaborative management? Public Adm. Rev. 2006, 66, 111-121. [CrossRef]

54. Rodriguez-Melo, A.; Mansouri, S.A. Stakeholder engagement: Defining strategic advantage for sustainable construction. Bus. Strategy Environ. 2011, 20, 539-552. [CrossRef]

55. McDougall, P.; Robinson, R.B., Jr. New venture strategies: An empirical identification of eight 'archetypes' of competitive strategies for entry. Strateg. Manag. J. 1990, 11, 447-468. [CrossRef]

56. Kriauciunas, A.; Parmigiani, A.; Rivera-Santos, M. Leaving our comfort zone: Integrating established practices with unique adaptations to conduct survey-based strategy research in nontraditional contexts. Strateg. Manag. J. 2011, 32, 994-1010. [CrossRef]

57. Karros, D.J. Statistical methodology: II. Reliability and validity assessment in study design, Part B. Acad. Emerg. Med. 1997, 4, 144-147. [CrossRef]

58. Kline, P. Handbook of Psychological Testing, 2nd ed.; Routledge: London, UK, 1999.

59. Waddock, S.A. Understanding social partnerships: An evolutionary model of partnership organizations. Adm. Soc. 1989, 21, 78-100. [CrossRef]

60. Waddock, S.A. Building successful social partnerships. MIT Sloan Manag. Rev. 1988, $29,17$.

61. Le Ber, M.J.; Branzei, O. Towards a critical theory of value creation in cross-sector partnerships. Organization 2010, 17, 599-629. [CrossRef]

62. Kline, R.B. Principles and Practice of Structural Equation Modeling; Guilford Publications: New York, NY, USA, 2010.

63. Neter, J.; Wasserman, W.; Kutner, M.H. Applied Linear Regression Models; Irwin: Chicago, IL, USA, 1989.

64. Babbie, E.R. The Practice of Social Research, 10th ed.; Wadsworth Publishing Company: Belmont, CA, USA, 2004.

65. Provan, K.G.; Kenis, P. Modes of network governance: Structure, management, and effectiveness. J. Public Adm. Res. Theory 2007, 18, 229-252. [CrossRef] 
66. Provan, K.G.; Milward, H.B. Do networks really work? A framework for evaluating public-sector organizational networks. Public Adm. Rev. 2001, 61, 414-423. [CrossRef]

67. Arnstein, S.R. A ladder of citizen participation. J. Am. Inst. Plan. 1969, 35, 216-224. [CrossRef]

68. Austin, J.E.; Seitanidi, M.M. Collaborative value creation: A review of partnering between nonprofits and businesses: Part 1. Value creation spectrum and collaboration stages. Nonprofit Volunt. Sect. Q. 2012, 41, 726-758. [CrossRef]

69. Austin, J.E.; Seitanidi, M.M. Collaborative value creation: A review of partnering between nonprofits and businesses: Part 2. Partnership processes and outcomes. Nonprofit Volunt. Sect. Q. 2012, 41, 929-968. [CrossRef]

70. Branzei, O.; Le Ber, M.J. Theory-method interfaces in cross-sector partnership research. In Social Partnerships and Responsible Business; Seitanidi, M.M., Crane, A., Eds.; Routledge Taylor \& Francis Group: London, UK, 2014; pp. 229-266.

71. Murphy, M.; Arenas, D.; Batista, J.M. Value creation in cross-sector collaborations: The roles of experience and alignment. J. Bus. Ethics 2015, 130, 145-162. [CrossRef]

72. Esteban, J. Collective action and the group size paradox. Am. Polit. Sci. Rev. 2001, 95, 663-672. [CrossRef]

73. Yan, X.; Lin, H.; Clarke, A. Cross-Sector Social Partnerships for Social Change: The Roles of Non-Governmental Organizations. Sustainability 2018, 10, 558. [CrossRef]

74. Albers, S.; Wohlgezogen, F.; Zajac, E.J. Strategic alliance structures: An organization design perspective. J. Manag. 2016, 42, 582-614. [CrossRef]

75. Geddes, M. Inter-organizational relationships in local and regional development partnerships. In The Oxford Handbook of Inter-Organizational Relations; Cropper, S., Ebers, M., Huxham, C., Ring, P.S., Eds.; Oxford University Press: Oxford, UK, 2008; pp. 203-230.

76. Huxham, C.; Vangen, S.E. Managing to Collaborate: The Theory and Practice of Collaborative Advantage; Routledge: New York, NY, USA, 2005.

77. Googins, B.K.; Rochlin, S.A. Creating the partnership society: Understanding the rhetoric and reality of cross-sectoral partnerships. Bus. Soc. Rev. 2000, 105, 127-144. [CrossRef]

78. Smardon, R.C. A comparison of Local Agenda 21 implementation in North American, European and Indian cities. Manag. Environ. Qual. Int. J. 2008, 19, 118-137. [CrossRef]

79. Cuthill, M. The contribution of human and social capital to building community well-being: A research agenda relating to citizen participation in local governance in Australia. Urban Policy Res. 2003, 21, 373-391. [CrossRef]

(C) 2019 by the authors. Licensee MDPI, Basel, Switzerland. This article is an open access article distributed under the terms and conditions of the Creative Commons Attribution (CC BY) license (http:/ / creativecommons.org/licenses/by/4.0/). 